\title{
Isolation and Characterization of Antibacterial Actinomycetes from Soil Samples of Kalapatthar, Mount Everest Region
}

\author{
Tara Devi Gurung ${ }^{1}$, Chringma Sherpa ${ }^{1}$, Vishwanath Prasad Agrawal ${ }^{2}$ and Binod Lekhak ${ }^{1}$ \\ ${ }^{1}$ Central Department of Microbiology, Tribhuvan University, Kirtipur, Nepal \\ Nepal Academy of Science and Technology, Khumaltar, Lalitpur
}

\begin{abstract}
Seventy-nine Actinomycetes were isolated from soils of Kalapatthar (5545m), Mount Everest region. Twenty seven $(34.18 \%)$ of the isolates showed an antibacterial activity against at least one test-bacteria among two Gram positive and nine Gram negative bacteria in primary screening by perpendicular streak method. Thirteen $(48.15 \%)$ showed antibacterial activity in secondary screening. The result showed that three of the isolates, K.6.3, K.14.2, and K.58.5 were highly active with an inhibition zone e" $20 \mathrm{~mm}$ and broad spectrum antibacterial activity including two methicillin resistant Staphylococcus aureus (MRSA) strains. Minimum inhibitory concentration (MIC) of antibacterial metabolites of the isolate K.6.3 was $1 \mathrm{mg} / \mathrm{ml}$, and that of isolates K.14.2 and K.58.5 was $2 \mathrm{mg} / \mathrm{ml}$. Two spots were detected on thin layer chromatography plate from each of the metabolites which was completely different from the spot produced by vancomycin. The active isolates from primary screening were heterogeneous in their overall macroscopic, biochemical, and physiological characteristics through unweighted pair group method using average (UPGMA) cluster analysis. Delineation of the three active isolates showing potent broad spectrum antibacterial activity revealed that they belonged to distinct taxonomic groups.
\end{abstract}

Key words: antibacterial activity, minimum inhibitory concentration, thin layer chromatography

\section{Introduction}

Microbial diversity is a vast frontier and potential goldmine for the biotechnology industry because it offers countless new genes and biochemical pathways to probe for enzymes, antibiotics and other useful molecules (Singh \& Agrawal 2002). The diversity of terrestrial Actinomycetes are of extraordinary significance in several areas of science and medicine, particularly in antibiotic production (Magarvey et al. 2004). Actinomycetes are diverse group of Grampositive bacteria that usually grow by filament formation. They belong to the order Actinomycetales (Superkingdom: Bacteria, Phylum: Firmicutes, Class: Actinobacteria, Subclass: Actinobacteridae). They have high $\mathrm{G}+\mathrm{C}(>55 \%)$ content in their DNA. They are the best common source of antibiotics, and provide approximately two-third of naturally occurring antibiotics, including many of medical importance (Okami \& Hotta 1988).
Need of new antimicrobial agents is greater than ever because of emergence of multidrug resistance in common pathogens, the rapid emergence of new infections and the use of multidrug resistant pathogens in bioterrorism (Spellberg et al. 2004). Resistance of bacteria to the effects of antibiotics has been a major problem in the treatment of diseases. Infectious diseases are still the second leading cause of death worldwide (WHO 2002, Luzhetskyy et al. 2007).

Though the recent quests for novel antibiotics have employed more recently established approach of target-based discovery using bacterial genomics, combinatorial chemistry, and high-throughput screening, these powerful tools have not yet yielded any antibiotics approved for clinical use, and the prospects for their success are not encouraging (Baltz 2007). On the other hand, programs aimed at the 
discovery of antibiotics from microbial sources have yielded an impressive number of compounds over the past 50 years, many of which have application in human medicine and agriculture (Busti et al. 2006). Hence, the traditional method of screening antibiotics from microorganisms is no longer considered glitzy science (Baltz 2007).

Choice of natural materials like soils in researches is based on the assumption that samples from widely diverse locations are more likely to yield novel microorganisms and therefore hopefully, novel metabolites as a result of the geographical variation (Sen et al. 1993). Besides, the important approaches helpful in discovering new microbial species or unknown bioactive substances include isolation and characterization of microorganisms from the most extreme habitations (Lee \& Hwang 2002) and relatively unknown or unstudied areas (Moncheva et al. 2002). In this regard, Kalapatthar (5545m), Mount Everest region of Nepal is of significant interest. Its high altitude and seasonal snow create extreme habitation which is likely to harbor unusual types of microorganisms while poorly studied habitation increases chance of finding novel microorganisms. Keeping these points in view, the present study was undertaken to isolate and characterize antibacterial Actinomycetes from soil samples of this area.

\section{Materials and Methods}

Collection of soil samples: Soil samples were collected from different sites of Kalapatthar in November 2006. Preferably dry soil samples (4-5g for each) were collected from depth of 4-5 cm and placed in clean polyethylene bags and mixed well with approximately $1 \mathrm{gm}$ of $\mathrm{CaCO}_{3}$, already added to the bag. Then the samples were further dried at room temperature for about three weeks.

Isolation of Actinomycetes: Actinomycetes were isolated by spread plate technique following the serial dilution of soil samples on starch casein agar (Williams \& Davies 1965) plates containing cycloheximide and nystatin (each at concentration of $50 \mu \mathrm{g} / \mathrm{ml}$ of medium).

\section{Screening of Actinomycetes for antibacterial activity:}

The screening method consists of two steps, Primary screening and secondary screening. Primary screening of Actinomycetes isolates was done by perpendicular streak method (Egorov 1985) on nutrient agar (NA). The test bacteria were Escherichia coli ATCC-25922, Proteus mirabilis ATCC- 49132, P. vulgaris, Klebsiella pneumoniae, K. oxytoca, Staphylococcus aureus ATCC-29213, Bacillus subtilis, Shigella species, Salmonella typhi and Salmonella paratyphi A. Secondary screening of Actinomycetes isolates was done by agar cup assay method on Mueller Hinton agar (MHA). The isolates possessing broad-spectrum antibacterial activity were further tested against two methicillin resistant $S$. aureus (MRSA) strains by both perpendicular streak method and agar cup assay method

Characterization of Actinomycetes: The potent Actinomycetes isolates selected from primary screening were characterized by morphological, biochemical and physiological methods. The morphological method consists of macroscopic and microscopic characterization. Macroscopically the Actinomycetes isolates were differentiated by their colony characters, e.g. size, shape, color, consistency etc. For the microscopy, the isolates were grown by cover slip culture method (Kawato \& Sinobu 1979). They were then observed for their mycelial structure, and conidiospore and arthrospore arrangements on the mycelia under microscope (1000X). The observed morphology of the isolates was compared with the Actinomycetes morphology provided in Bergey's Manual for the presumptive identification of the isolates.

Various biochemical tests performed were catalase, oxidase, citrate utilization, nitrate reduction, starch hydrolysis, tween 20 hydrolysis, urea hydrolysis, gelatin hydrolysis, esculin hydrolysis, acid production from sugar, and the physiological test included motility, $\mathrm{NaCl}$ resistance, and temperature tolerance.

Fermentation: The isolates possessing broad-spectrum antibacterial activity in both primary and secondary screening were selected for fermentation. Fermentation was carried out by the submerged state culture in Erlenmeyer flask (1lit.).

Isolation of antibacterial metabolites: The filtrate was subjected for solvent extraction method to recover antibacterial metabolites in pure form (Liu et al. 1986). Ethyl acetate was added to the filtrate in the ratio of $1: 1(\mathrm{v} / \mathrm{v})$ and shaken vigorously for $1 \mathrm{~h}$ for complete extraction. The phase having antibacterial property was poured in porcelain basin for evaporation. It was evaporated in water bath at $40^{2 \%} \mathrm{C}$ and the residue obtained was weighed and dissolved in phosphate buffer for preservation. Other organic solvents like n- butanol, 
Tara Devi Gurung et al./solation and Characterization.......

chloroform, dichloromethane and methanol were also used to extract the antibacterial metabolites by the same procedure.

Determination of antibacterial activity: The antimicrobial activity of the concentrated metabolites was determined by agar cup assay method.

\section{Determination of minimum inhibitory concentration:}

The minimum inhibitory concentration of the metabolites was determined by serial dilution method in nutrient broth against $S$. aureus ATCC 29213.

Thin layered chromatography: Ten micro litre of each antimicrobial metabolite $(30 \mathrm{mg} / \mathrm{ml})$ and standard antibiotic (Vancomycin) were applied separately on a $10 \mathrm{~cm} X 20 \mathrm{cmX} 1 \mathrm{~mm}$ Silica gel plate, and the chromatogram was developed using chloroform: methanol (10:90) as solvent system. The spots were visualized in the iodine vapor chamber.

\section{Results}

Seventy-nine different types of Actinomycetes were isolated based on differences in the colony morphology.

Screening of isolated Actinomycetes for antimicrobial activity: Twenty-seven $(34.18 \%)$ out of 79 Actinomycetes isolates showed antibacterial activity against one or more test bacteria in primary screening. Among which 17 were active against Gram positive bacteria only, three against Gram negative bacteria only and seven against both Gram positive and Gram negative bacteria. Among them, 19 isolates showed activity against $S$. aureus ATCC 29213, 18 against $B$. subtilis, five against $S$. typhi, eight against $S$. paratyphi, three against E. coli ATCC 25922, Shigella spp. and $P$. mirabilis ATCC 49132, five against $P$. vulgaris, and four against $K$. pneumoniae and $K$. oxytoca, (Table 1$)$. Three Actinomycetes isolates namely K.6.3, K.14.2, and K.58.5 showed broad spectrum antibacterial activity against all test bacteria, inhibiting growth along entire streak line on the agar plate (Fig. 1). In addition, they showed very active inhibitory action against MRSA ATCC 40 and MRSA ATCC 42 strains too.

Table 1. Zone of inhibition of active isolates in primary screening

\begin{tabular}{|c|c|c|c|c|c|c|c|c|c|c|c|}
\hline \multirow[b]{3}{*}{$\begin{array}{c}\text { Serial } \\
\text { No. }\end{array}$} & \multirow{3}{*}{$\begin{array}{l}\text { Actino- } \\
\text { mycetes } \\
\text { isolates }\end{array}$} & \multicolumn{10}{|c|}{ Zone of inhibition (in $\mathrm{mm}$ ) against test bacteria } \\
\hline & & \multicolumn{8}{|c|}{ Gram negative bacteria } & \multicolumn{2}{|c|}{ Gram positive bacteria } \\
\hline & & S. typhi & $\begin{array}{l}\text { S. } \\
\text { paratyphi }\end{array}$ & $\begin{array}{l}\text { E. coli } \\
\text { ATCC } \\
25922\end{array}$ & $\begin{array}{l}P . \\
\text { mirabilis } \\
\text { ATCC } \\
49132\end{array}$ & $\begin{array}{c}P . \\
\text { vulgaris }\end{array}$ & $\begin{array}{c}\text { K. } \\
\text { pneum } \\
\text { oniae }\end{array}$ & $\begin{array}{c}K . \\
\text { oxytoca }\end{array}$ & $\begin{array}{l}\text { Shigella } \\
\text { spp. }\end{array}$ & $\begin{array}{l}\text { S. aureus } \\
\text { ATCC } \\
29213\end{array}$ & $\begin{array}{l}\text { B. } \\
\text { subtilis }\end{array}$ \\
\hline 1 & K.6.3 & $\mathrm{NG}^{\mathrm{a}}$ & $\mathrm{NG}$ & $\mathrm{NG}$ & NG & $\mathrm{NG}$ & $\mathrm{NG}$ & NG & $\mathrm{NG}$ & NG & $\mathrm{NG}$ \\
\hline 3 & K. 58.5 & NG & NG & NG & NG & $\mathrm{NG}$ & $\mathrm{NG}$ & $\mathrm{NG}$ & NG & NG & $\mathrm{NG}$ \\
\hline 4 & K. 5.1 & 0 & 20 & 0 & 0 & 0 & 0 & 0 & 0 & 0 & 0 \\
\hline 5 & K. 5.2 & 0 & 20 & 0 & 0 & 0 & 0 & 0 & 0 & 0 & 0 \\
\hline 6 & K.6.1 a & 0 & 0 & 0 & 0 & 2 & 2 & 0 & 0 & 20 & 17 \\
\hline 7 & K.6.1b & 0 & 0 & 0 & 0 & 0 & 0 & 0 & 0 & 16 & 5 \\
\hline 8 & K. 6.8 & 0 & 0 & 0 & 0 & 0 & 0 & 0 & 0 & 16 & 16 \\
\hline 9 & K.7.2 & 0 & 0 & 0 & 0 & 0 & 0 & 0 & 0 & 13 & 0 \\
\hline 10 & K. 7.4 & 0 & 0 & 0 & 0 & 0 & 0 & 0 & 0 & 10 & 0 \\
\hline 12 & K. 8.2 & 0 & 20 & 0 & 0 & 0 & 0 & 20 & 0 & 0 & 5 \\
\hline 13 & K.9.2 & 0 & 0 & 0 & 0 & 3 & 0 & 0 & 0 & 0 & 0 \\
\hline 14 & K. 16.4 & 16 & 20 & 0 & 0 & 0 & 0 & 0 & 0 & 0 & 20 \\
\hline 15 & K. 16.7 & 0 & 0 & 0 & 0 & 0 & 0 & 0 & 0 & 0 & 10 \\
\hline 16 & K. 18.1 & 0 & 0 & 0 & 0 & 0 & 0 & 0 & 0 & 10 & 0 \\
\hline 17 & K. 48.1 & 0 & 0 & 0 & 0 & 0 & 0 & 0 & 0 & 20 & 4 \\
\hline 18 & K. 48.2 & 0 & 0 & 0 & 0 & 0 & 0 & 0 & 0 & 15 & 10 \\
\hline 19 & K.48.3 & 0 & 0 & 0 & 0 & 0 & 0 & 0 & 0 & 0 & 10 \\
\hline 20 & K. 60.2 & 0 & 0 & 0 & 0 & 0 & 0 & 0 & 0 & 15 & 12 \\
\hline 21 & K. 60.4 & 8 & 5 & 0 & 0 & 0 & 0 & 0 & 0 & 20 & 0 \\
\hline 22 & K.69.3 & 0 & 0 & 0 & 0 & 0 & 0 & 0 & 0 & 16 & 10 \\
\hline 23 & K. 70.1 & 0 & 0 & 0 & 0 & 0 & 0 & 0 & 0 & 0 & 10 \\
\hline 24 & K. 70.2 & 0 & 0 & 0 & 0 & 0 & 0 & 0 & 0 & 20 & 20 \\
\hline 25 & K. 70.3 & 0 & 0 & 0 & 0 & 0 & 0 & 0 & 0 & 7 & 0 \\
\hline 26 & K. 100.1 & 0 & 0 & 0 & 0 & 0 & 0 & 0 & 0 & 8 & 0 \\
\hline 27 & K. 100.2 & 0 & 0 & 0 & 0 & 0 & 0 & 0 & 0 & 22 & 25 \\
\hline
\end{tabular}

${ }^{a} \mathrm{NG}=$ No growth; the inhibition of bacterial growth along the whole perpendicular streak line 


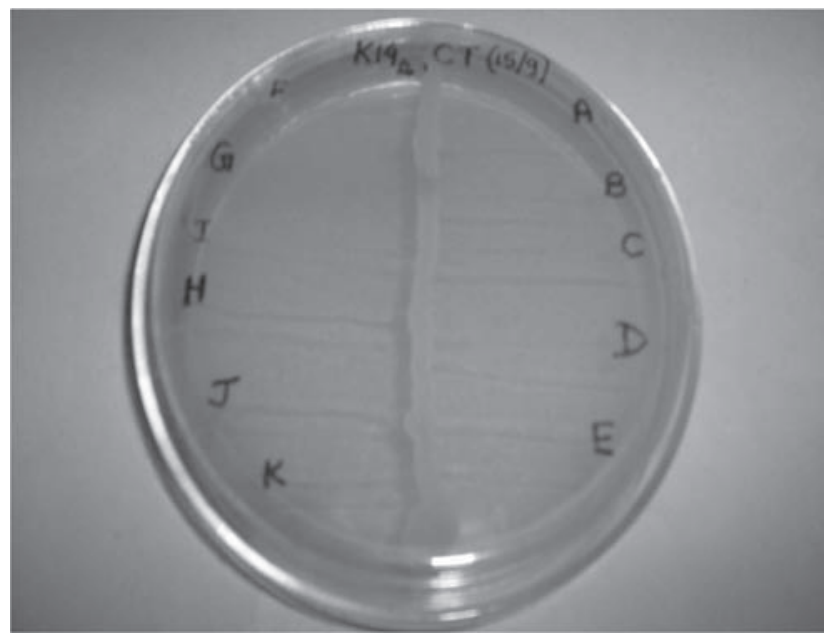

Fig.1. Primary screening of isolate K.14.2 against test bacteria by perpendicular streak method. A, S. typhi; B, $S$. paratyphi A; C, E. coli ATCC 25922 ; D, P. mirabilis ATCC 49132; E, P. vulgaris; F, K. pneumoniae; G, $P$. aeruginosa ATCC 27853; H, K. oxytoca; I, Shigella spp.; J, S. aureus ATCC 29213; K, B. subtilis

Note: The growth along the central streak is that of Actinomycete. The growth of all the perpendicularly streaked test bacteria except $P$. aeruginosa is completely inhibited.

Out of 27 isolates that were subjected for the secondary screening, $13(48.15 \%)$ showed antibacterial activity against at least one of the test bacteria (Table 2). The three isolates (K.6.3, K.14.2.and K.58.5) with broad spectrum antibacterial activity in primary screening again showed inhibitory action against all test bacteria including two strains of MRSA in the secondary screening (Fig. 2).

Table 2. Zone of inhibition of active isolates in secondary screening.

\begin{tabular}{|c|c|c|c|c|c|c|c|c|c|c|c|}
\hline \multirow{3}{*}{$\begin{array}{l}\text { Serial } \\
\text { No. }\end{array}$} & \multirow{3}{*}{$\begin{array}{c}\text { Actinomycetes } \\
\text { isolates }\end{array}$} & \multicolumn{10}{|c|}{ Zone of inhibition ( in mm ) against test bacteria ${ }^{a}$} \\
\hline & & \multicolumn{8}{|c|}{ Gram negative bacteria } & \multicolumn{2}{|c|}{$\begin{array}{l}\text { Gram positive } \\
\text { bacteria }\end{array}$} \\
\hline & & S. typhi & $\begin{array}{l}S . \\
\text { paratyphi }\end{array}$ & $\begin{array}{l}\text { E. coli } \\
\text { ATCC } \\
25922\end{array}$ & $\begin{array}{l}P . \\
\text { mirabilis } \\
\text { ATCC } \\
49132\end{array}$ & P. vulgaris & $\begin{array}{l}\text { K. } \\
\text { pneum } \\
\text { oniae }\end{array}$ & K. & $\begin{array}{l}\text { Shigella } \\
\text { spp }\end{array}$ & $\begin{array}{l}\text { S. aureus } \\
\text { ATCC } \\
29213\end{array}$ & $\begin{array}{l}\text { B. } \\
\text { subtil }\end{array}$ \\
\hline 1 & K.6.3 & 21 & 20 & 17 & 14 & 10 & 17 & 11 & 17 & 18 & 13 \\
\hline 2 & K.14.2 & 22 & 20 & 17 & 16 & 10 & 14 & 10 & 17 & 20 & 12 \\
\hline 3 & K.58.5 & 16 & 20 & 17 & 17 & 14 & 11 & 14 & 13 & 20 & 11 \\
\hline 4 & K.6.8 & 0 & 0 & 0 & 0 & 0 & 0 & 0 & 0 & 0 & 11 \\
\hline 5 & K.16.4 & 0 & 0 & 0 & 0 & 0 & 0 & 0 & 0 & 0 & 15 \\
\hline 6 & K.48.1 & 0 & 0 & 0 & 0 & 0 & 0 & 0 & 0 & 0 & 11 \\
\hline 7 & K.48.2 & 0 & 0 & 0 & 0 & 0 & 0 & 0 & 0 & 0 & 11 \\
\hline 8 & K. 48.3 & 0 & 0 & 0 & 0 & 0 & 0 & 0 & 0 & 0 & 11 \\
\hline 9 & K.60.2 & 0 & 0 & 0 & 0 & 0 & 0 & 0 & 0 & 14 & 18 \\
\hline 10 & K.70.1 & 0 & 0 & 0 & 0 & 0 & 0 & 0 & 0 & 0 & 11 \\
\hline 11 & K.70.3 & 0 & 0 & 0 & 0 & 0 & 0 & 0 & 0 & 0 & 16 \\
\hline 12 & K.100.1 & 0 & 0 & 0 & 0 & 0 & 0 & 0 & 0 & 10 & 0 \\
\hline 13 & K.100.2 & 0 & 0 & 0 & 0 & 0 & 0 & 0 & 0 & 0 & 14 \\
\hline
\end{tabular}




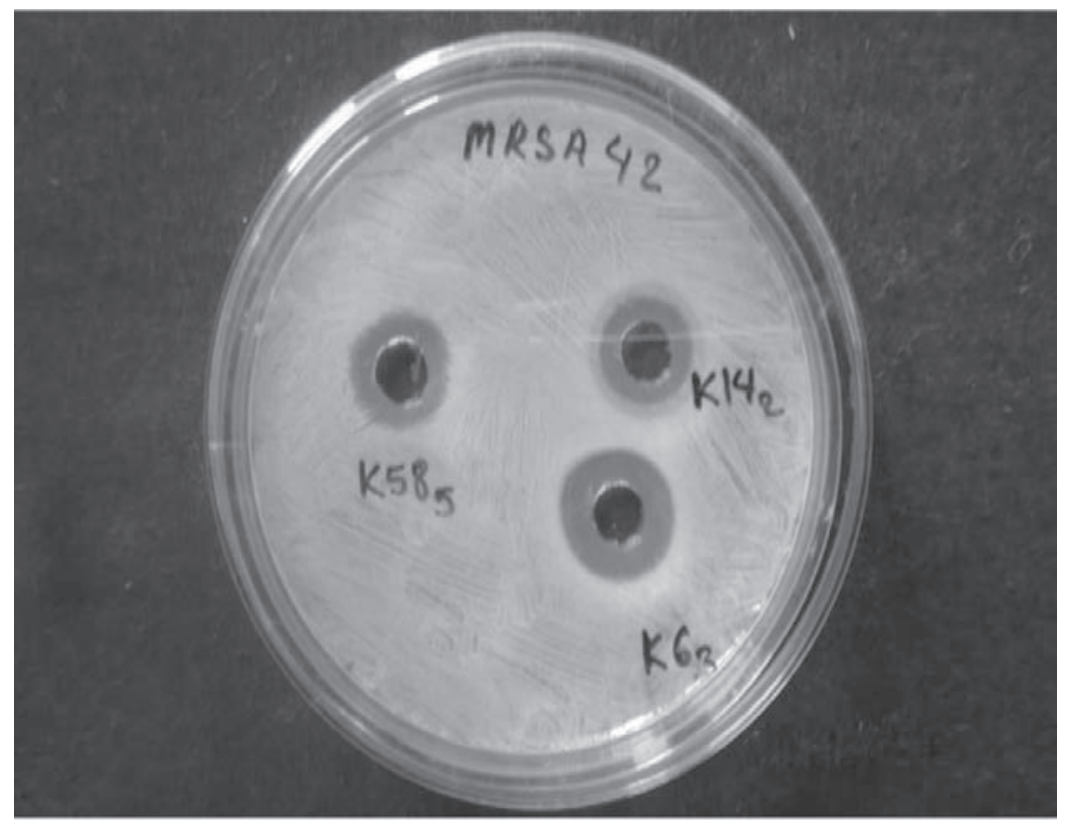

Fig.2. Secondary screening of actinomycetes isolates K.6.3, K.14.2 and K.58.5 against MRSAATCC 42 by agar cup assay method

Table 3. Zone of inhibition of the broad spectrum antibiotic producing isolates against MRSA strains

\begin{tabular}{l|l|r|r|r|r}
\hline \multirow{2}{*}{ Serial No. } & \multirow{2}{*}{$\begin{array}{l}\text { Actinomycetes } \\
\text { isolates }\end{array}$} & \multicolumn{3}{|c}{ Zone of inhibition against test bacteria } \\
\cline { 3 - 6 } & & \multicolumn{2}{|c}{ MRSA ATCC 40 } & \multicolumn{2}{|c}{ MRSAATCC 42 } \\
\cline { 3 - 6 } 1 & K.6.3 & No growth & $18 \mathrm{~mm}$ & No growth & $18 \mathrm{~mm}$ \\
2 & K.14.2 & No growth & $15 \mathrm{~mm}$ & No growth & $15 \mathrm{~mm}$ \\
3 & K.58.5 & No growth & $15 \mathrm{~mm}$ & No growth & $15 \mathrm{~mm}$ \\
\hline
\end{tabular}

b No growth; the inhibition of bacterial growth along the whole perpendicular streak line

Identification: Based on their mycelial and cellular morphology observed under microscope (1000X), the antibacterial Actinomycetes isolates were identified as Streptomyces (16 isolates) (Fig. 4), Micromonospora (2 isolates) (Fig. 6),
Intrasporangium (1 isolate) (Fig. 7), and Streptosporangium (1 isolate). The remaining seven active isolates were unidentified (Fig. 5). Among Streptomyces spp., six had retinaculiaperti, nine had rectiflexibles and one had spirales type sporophore morphology (Fig. 3). 
Nepal Journal of Science and Technology 10 (2009) 173-182

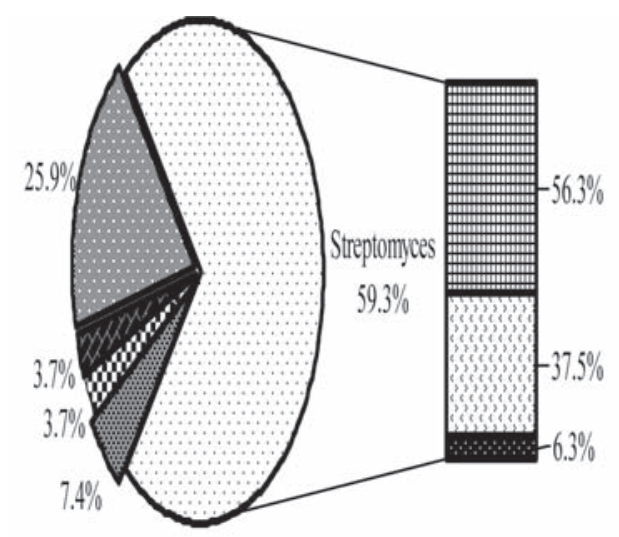

Micromonospora Intrasporangium Streptosporangium Unidentified ORectillexible ORetimaculapetri Spriale

Fig.3. Presumptive genera of the active isolates identified by light microscopy (X1000)

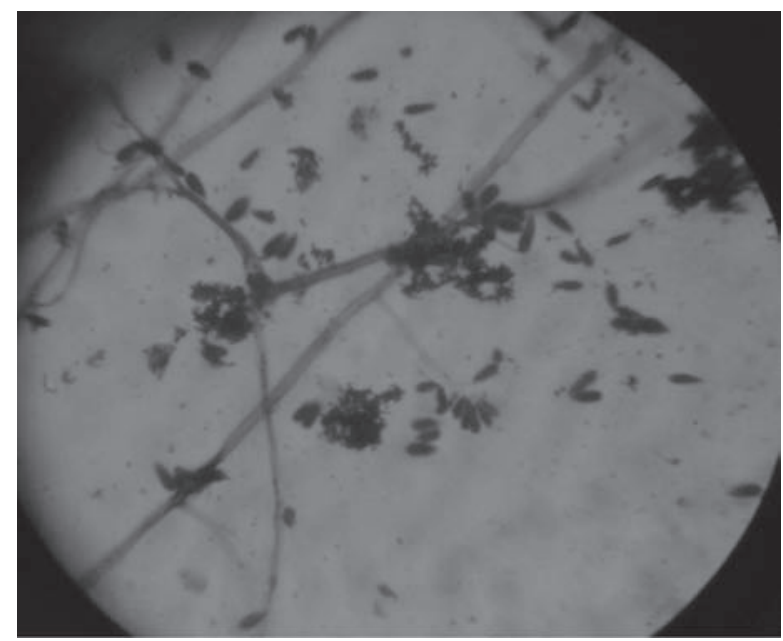

Fig.5. Photomicrograph of Actinomycete isolate K. 48.1 (unidentified) (X1000)

Note: Mycelium with sessile bottle shaped spores

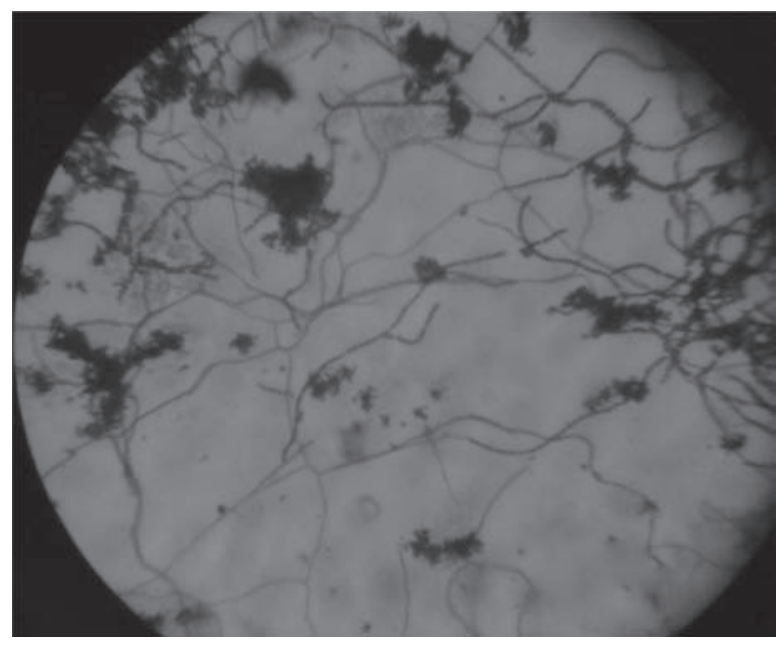

Fig.4. Photomicrograph of actinomycete isolate K.7.2 (presumptive Streptomyces spp.) (X1000)

Note: Sporophore morphology is rectiflexible.

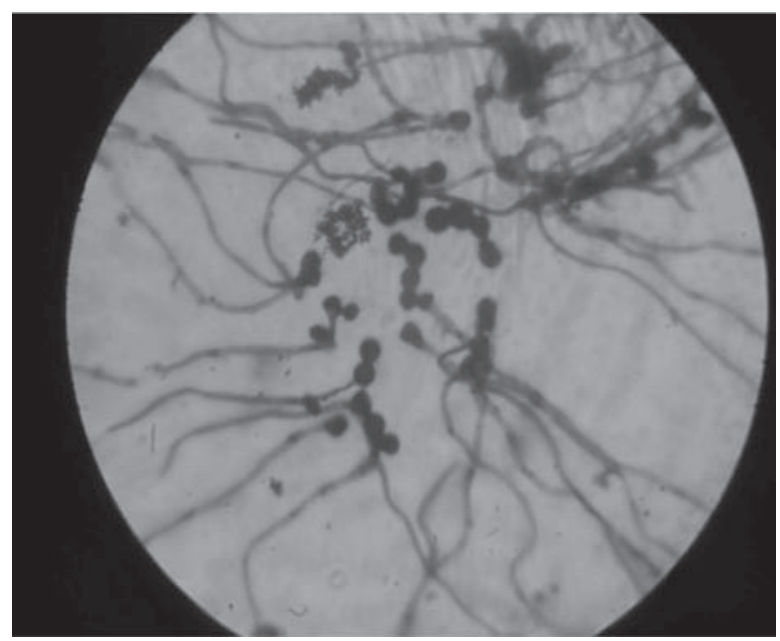

Fig.6. Photomicrograph of Actinomycete isolate K. 100.1 (presumptive Micromonospora spp.) (X1000)

Note: mycelial tips bear single spore and some multiple longitudinal spores 


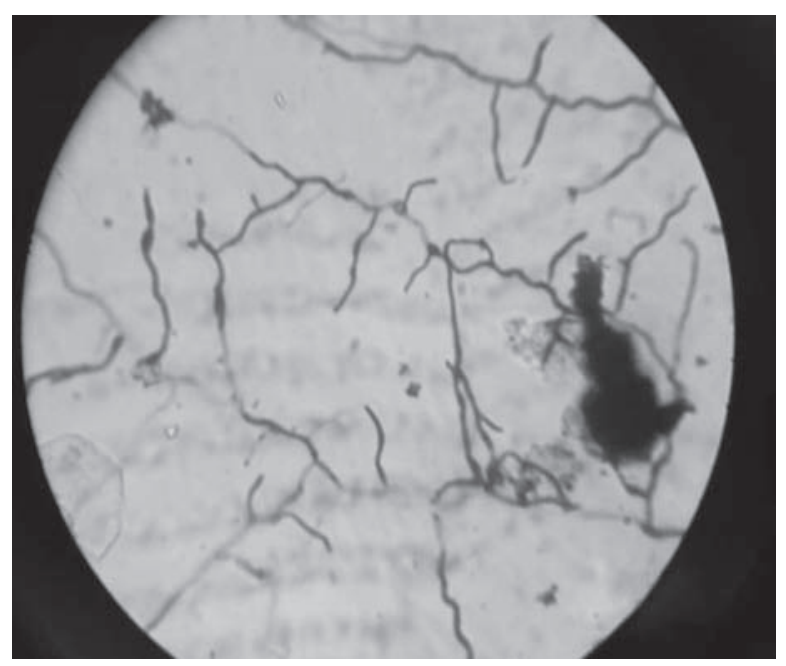

Fig.7. Photomicrograph of Actinomycete isolate K. 100.3 (presumptive Intrasporangium spp.) (X1000)
Fermentation: The fermented broth from all three isolates Viz. K.6.3, K.14.2 and K.58.5 showed antibacterial activity against all the test bacteria.

Isolation of antibacterial metabolites: None of the tested organic solvents (n butanol, chloroform, dichloromethane, ethyl acetate and methanol) could extract the antibacterial metabolites from the filtrates of fermented broths in detectable level by solvent extraction method. Hence, the filtrates themselves were evaporated at $40^{\mathrm{x} \%} \mathrm{C}$ to concentrate the metabolites up to $1 \mathrm{~g}$ per $100 \mathrm{ml}$ for the isolates K.6.3 and K.58.5, and $1.33 \mathrm{~g}$ per $100 \mathrm{ml}$ for the isolate $\mathrm{K} .14 .2$. The residues obtained from K.6.3 and K.14.2 were brown in color and had sticky/greasy consistency, whereas that of K.58.5 was light brown in color and flaky consistency. The residues were dissolved in minimum amount of phosphate buffer for preservation.

Rescaled Distance Cluster Combine

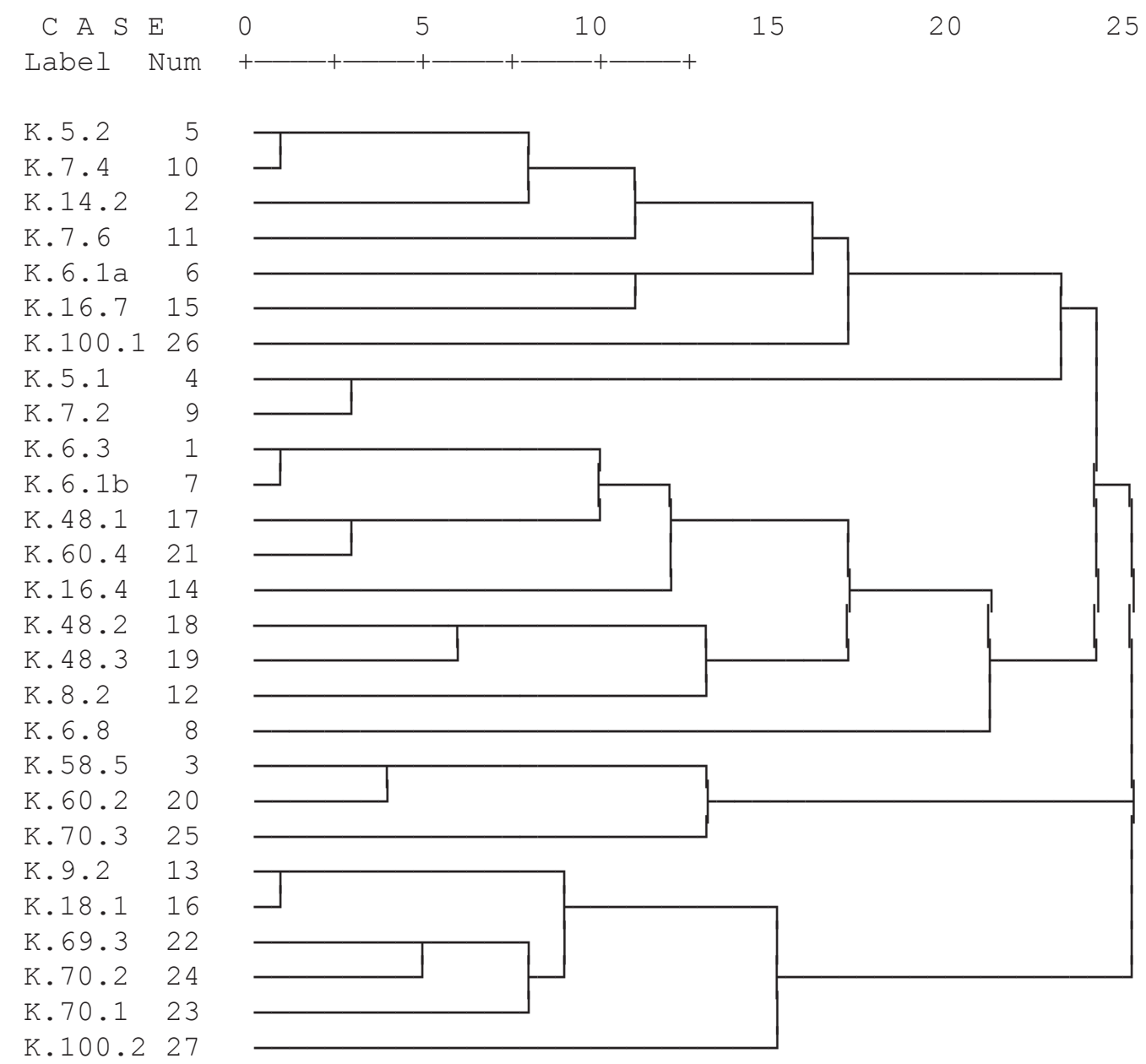


Minimum inhibitory concentration: The minimum inhibitory concentration of the crude metabolites from isolate K.6.3 was $1 \mathrm{mg} / \mathrm{ml}$, and that of K.14.2 and K.58.5 $2 \mathrm{mg} / \mathrm{ml}$ against $S$. aureus ATCC 29213.

Characterization of antibacterial substances: When visualized by iodine vapor, each extract showed two spots; one at the point of loading itself, and the other near to the solvent front on the chromatogram. The retention factors $\left(\mathrm{R}_{\mathrm{f}}\right)$ of moved spot were 0.88 for the isolate K.6.3, 0.86 for K.14.2 and 0.95 for K.58.5. The control sample, vancomycin produced only one tailed spot with $R_{f}$ value of 0.09 .

Hierarchical cluster analysis: All the active Actinomycetes isolates were subjected to hierarchical cluster analysis on the basis of a total of 50 macroscopic, biochemical and physiological characters. The unweighted pair-group method using averages (UPGMA) dendrograms based on Nei and Li's coefficient were generated by SPSS 11.5 software. At $50 \%$ similarity, three clusters were generated. The first cluster contained 18 Actinomycetes isolates. The second cluster contained three Actinomycetes. The third cluster contained six Actinomycetes isolates. At $80 \%$ similarity, 22 clusters were generated. The $1^{\text {st }}$ cluster contained isolates K.5.2 and K.7.4 with the highest Nei and Li's similarity coefficient of 0.828 . The $2^{\text {nd }}, 3^{\text {rd }}, 4^{\text {th }}, 5^{\text {th }}$, and $6^{\text {th }}$ clusters were formed by K.14.2, K.7.6, K.6.1a, K.16.7, and K.100.1 respectively. The $7^{\text {th }}$ cluster was formed by K.5.1 and K.7.2. The $8^{\text {th }}$ cluster was formed by K.6.3 and K.6.1b. The $9^{\text {th }}$ cluster was formed by K.48.1 and K.60.4. The $10^{\text {th }}, 11^{\text {th }}, 12^{\text {th }}, 13^{\text {th }}, 14^{\text {th }} 15^{\text {th }}, 16^{\text {th }}$, and $17^{\text {th }}$ clusters were formed by K.16.4, K.48.2, K.48.3,K.8.2, K.6.8, K.58.5, K.60.2, and K.70.3 respectively. The $18^{\text {th }}$ cluster was formed by K.9.2 and K.18.1. The $19^{\text {th }}, 20^{\text {th }}, 21^{\text {st }}$ and $22^{\text {nd }}$ clusters were formed by K.69.3, K.70.2, K.70.1, and K.100.2 respectively (Fig. 8).

\section{Discussion}

Seventy-nine different types of Actinomycetes were isolated from the soils of Kalapatthar. The survival of the microorganisms in such harsh and challenging habitation might be due to their adaptation to the environment and ability to produce resistant structures like spores.

Isolation of Actinomycetes has always been faced with difficulties in comparison to their competitors like other bacteria and fungi (Williams \& Cross 1971). This may be due to their long incubation period. However, the Actinomycetes isolation ratio was increased by pretreatment of the samples by calcium carbonate and subjecting them in to air dry for three weeks. Use of selective media (starch casein media) incorporation with antibiotics, cycloheximide $(50 \mu \mathrm{g} / \mathrm{ml})$ and nystatin $(50 \mu \mathrm{g} /$ $\mathrm{ml}$ ) was crucial inhibiting contaminating microorganisms.

Both the primary and secondary screening methods were used to screen Actinomycetes for antibacterial activity. The first screening was used to select the antibacterial isolates and determine the range of microorganisms that were sensitive to the antibiotic. The secondary screening method was crucial to select the isolates for further studies. The screening may be qualitative or quantitative in its approach. The qualitative approach is used to determine the range of the microorganisms that are sensitive to a potential antibiotic. The quantitative approach provides the information about the yield of antibiotic that can be expected when the organism is grown in different media.

Out of 27, only 13 (48.15\%) active Actinomycetes selected from primary screening showed antibacterial activity in the secondary screening. This difference might be due to the difference in the morphology of Actinomycetes when grown in solid and liquid media as filamentous mycelia and fragmenting mycelia respectively (Bushell 1993), or the chemical modification of the active compounds to become inactive in broth culture.

The result of the screening revealed that more isolates were active against Gram positive bacteria than Gram negative bacteria. This might be due to the morphological differences between those two types of microorganisms. Gram negative bacteria have an outer lipopolysaccharide membrane; hence their cell wall is impermeable to lipophilic solutes, while porins constitute a selective barrier to the hydrophilic solutes (Nokaido \& Vaara 1985). The Gram positive bacteria have only peptidoglycan layer, not an effective permeability barrier for the antibacterial agents.

From the result of primary and secondary screening, three isolates K.6.3, K.14.2, and K.58.5 were found to be the best strains as they showed broad spectrum activity with big zone of inhibition (e"20 20 m). The isolates might produce more than one antibacterial metabolites that made them effective inhibitor to both Gram positive and Gram negative bacteria. Therefore, 
Tara Devi Gurung et al./solation and Characterization.......

the isolates were chosen for fermentation. The antibacterial metabolites from fermented broth were tried to extract in different organic solvents (n- butanol, chloroform, dichloromethane, ethyl acetate and methanol) by solvent extraction method. However, none of the solvent could extract the metabolites to detectable level. The possible reasons behind this could be (i) the presence of polar functional groups in the metabolites that made them instantly soluble in water than other less polar organic solvents, (ii) inadequate shaking of the mixture, and (iii) lack of appropriate solvent.

Minimum inhibitory concentration for the antibacterial metabolites extracted from K.6.3 was $1 \mathrm{mg} /$ $\mathrm{ml}$, and that of K.14.2 and K. 58.5 was $2 \mathrm{mg} / \mathrm{ml}$. Since these metabolites were obtained by the evaporation of crude filtrate, it was likely to have the high MIC value.

The crude extracts were further analyzed by thin layer chromatography on silica gel plate using chloroform and methanol (10:90) as solvent system, and vancomycin as control/standard antibiotic. Each extract produced two spots when the chromatogram was visualized under iodine vapor. One spot was at the point of sample loading and the other was near the solvent front with $\mathrm{R}_{\mathrm{f}}$ values of 0.88 for K.6.3, 0.86 for K.14.2, and 0.95 for K.58.5. Vancomycin, however, formed a tailed spot with $R_{f}$ value of about 0.09 . Since two spots were produced from each extract, the metabolite must contain at least two compounds. To detect which one or both of the compounds are active, bioautography is necessary.

Various phenotypic characteristics of the active isolates investigated in the study, showed metabolic heterogeneity among them. According to Kutzner (1981), for proper identification of genera and species of Actinomycetes, besides morphological and physiological properties, various other biochemical properties such as cell wall chemistry, whole cell sugar pattern, types of peptidoglycan and phospholipids, and $\mathrm{G}+\mathrm{C} \%$ of DNA should be determined. Numerical analysis of twenty seven active isolates using phenotypic (macroscopic, biochemical, and physiological) characteristics, by UPGMA dendrogram based on Nei and Li's coefficient grouped into 3 clusters at $50 \%$ similarity and 22 clusters at $80 \%$ similarity. The isolate K.14.2 was clustered along with 18 different isolates at $50 \%$ similarity, and at $80 \%$ similarity, it alone formed a single cluster. Thus the numerical analysis of isolate K.14.2 using UPGMA dendrogram of phenotypic data at $80 \%$ similarity placed isolate K.14.2 under distinct taxonomic group. At 50\% similarity the isolate K. 6.3 was clustered along with 18 different isolates and at $80 \%$ similarity, it was clustered along with one presumptive Streptomyces spp. (i.e. K.6.1b). Numerical analysis of the isolate K.58.5 using macroscopic, biochemical and physiological characteristics, revealed that at 50\% similarity, it was clustered with 2 different isolates, both of which were presumptive Stretpmyces spp., at $80 \%$ similarity, it alone formed a single cluster.

The finding that the potent broad-spectrum antibiotic producer K.14.2 isolated from extreme geographic and climatic area like Kalapatthar belongs to a distinct taxonomic group makes this isolate a promising candidate for discovering novel and potent antibiotic.

\section{Acknowledgement}

We thank Dr. Anjana Singh for granting her permission to work on this research, Mr. Temba Sherpa, Mr. Tsereing Mingur Sherpa, Mr. Phuri Sherpa for making this research possible by bringing us the soil samples all the way from Kalapatthar, Dr. Ronald Baeurle and Mrs. Judy Baeurle for being a source of motivation and inspiration for us throughout the research period. Mr. Kiran Babu Tiwari, Mr. Gyan Sundar Sahukhal, Mr.Upendra Thapa Shrestha for reviews of our work, Keshav Koirala, Rishi Baniya, Manita Guragain, and Nirajan Bhattarai for their valuable suggestions and timely help, and all the teaching and non teaching staff of RLABB and Central Department of Microbiology for the help rendered throughout the study period.

\section{References}

Baltz, R.H. 2007. Antimicrobials from actinomycetes: Back to the future. Microbe 2(3):125-131

Bergey's Manual of Determinative Bacteriology 1974. Buchanan, R.E., N.E. Gibbons, S.T. Cowan, J.G. Holt, J. Liston, R.G.E. Murary, C.F. Niven, A.W. Ravin and R.Y. Stainer (eds.), eighth edn, Williams \&Wilkins Company, Baltimore, U.S.A. pp. 659-881.

Bushell, M.E. 1993. A method for increasing the success rate of duplicating antibiotic activity in agar and liquid cultures of Streptomyces isolates in new antibiotics screens. Journal of Fermentation Bioengineering 76 (2): 89-93

Busti, E., P. Monociardini, L. Cavaletti, R. Bamonte, A. Lazzarini, M. Sosio and S. Donadio 2006. Antibioticproducing ability by representatives of a newly discovered lineage of Actinomycetes. Microbiology 152 : 675-683 
Casidia, L.E. 1959. Basis and development of industrial fermentation process, in industrial microbiology. $\left(6^{\text {th }}\right.$ edition). Wiley Eastern Limited publication

Egorov, N.S. 1985. Antibiotics, a scientific approach. Mir Publishers, Moscow

Kawato, M. and R. Shinobu 1959. A simple technique for the microscopical observation. Memoirs of the Osaka University Liberal Arts and Education $8: 114$.

Kutzner, H.J. 1981. The family Streptomycetaceae. In: The prokaryotes. A handbook on habitat, isolation, and identification of bacteria (Eds M.P. Starr, H. Stolp, H.G. Truper, A. Balows and H.G .Schlegel). SpringerVerlag, New York. Pp. 2028-2082

Lee, J.Y. and B.K. Hwang 2002. Diversity of antifungal Actinomycetes in various vegetative soils of Korea. Canidian Journal of Antibiotics 48 : 407.

Liu, C.M., J.W. Westley, T.E. Herman, B.L.T. Prasser, N. Palleroni, R.H. Evans and P.A. Miller 1986. Novel polyether antibiotics, X-14873 A, G and H produced by Streptomyces. Taxonomy of the producing culture, fermentation, biological and ionophores properties of the antibiotics. Journal of Antibiotics 39 (12) : 1712-1718

Luzhetskyy, A., S. Pelzer and A. Bechthold 2007. The future of natural products as a source of new antibiotics. Current Opinion in Investigational Drugs 8 (8) : 608-613

Magarvey, N.A., J.M. Keller, V. Bernan, M. Dworkin and D.H. Sherman 2004. Isolation and characterization of novel marine-derived Actinomycetes taxa rich in bioactive metabolites. Applied and Environmental Microbiology 70 (12) : 7520-7529.

Moncheva, P., S. Tishkov, N. Dimitrova, V. Chipeva, S.A. Chipeva, and N. Bogatzevska 2002. Characteristics of soil Actinomycetes from Antarctica. Journal of Culture Collections 3 pp. 3-14

Nokaido, H. and M. Vaara 1985. Molecular basis of bacterial outer membrane permeability. Microbiological Reviews 49 (1), 1-32

Okami, Y. and K. Hotta 1988. Search and discovery of new antibiotics. In: Actinomycetes in biotechnology (Eds. M. Good Fellow, S.T. Williams and M. Mordarski). Academic press, London pp. 37-67

Singh, D. and V.P. Agrawal 2002. Microbial Biodiversity of Mount Sagarmatha Region. In Proceedings of International Seminar on Mountains, March 6 - 8, Kathmandu. Nepal Academy of Science and Technology, Khumaltar, Lalitpur, Nepal pp. 357-360.

Spellberg, B., J.H. Powers, E.P. Brass, L.G. Miller and J.E. Edwards 2004. Trends in antimicrobial drug development: implications for the future. Clinical Infectious Diseases 38(9). 1279-1286

Williams, S.T. and T. Cross 1971. Actinomycetes, applied microbiology 4 Academic Presss

Williams, S.T. and F.L. Davies 1965. Use of antibiotics for selective isolation and enumeration of Actinomycetes in soil. Journal of General Microbiology 38: 251-261 WHO 2002. Deaths by cause, sex and mortality stratum in WHO Regions, estimates for 2001. World Health Report, World Health Organization. 